\title{
Experiences of School Development Associations in Zimbabwe: A case of Bulawayo Metropolitan High Density Secondary Schools.
}

\author{
Dr. Onias Mafa (Zimbabwe Open University) and Ms. Lilian Nyathi (Girls College - Bulawayo).
}

\begin{abstract}
In recent years, Zimbabweans have witnessed increased participation of parents and guardians through School Development Associations (SDAs) in the management of school development affairs. Several SDAs have constructed classrooms, computer laboratories and bought schools computers, school cars and buses. In almost all the public schools, SDAs are responsible for paying incentives - an allowance paid to teachers over and above their monthly salaries to cushion them from a depressed economy. However, SDAs activities have not always been smooth sailing. The purpose of this study was to explore the activities of SDAs, unmask the challenges they experience and suggest strategies to enhance the smooth operation of the SDAs. Ten school heads and ten SDA chairpersons who were purposively sampled formed the study sample. Data were generated through interviews. Major conclusions were that: the main challenges faced by SDAs in developing schools were inadequate financial resources; political interference; increasing numbers of vulnerable children and orphans and low qualifications of some of the SDA executive members. Recommendations included: capacitating SDA executive members through workshops; auditing of SDA funds by government auditors; stipulating the minimum qualifications of parents and guardians who should hold offices in SDAs and encouraging parents and guardians to attend SDA meetings and support SDA activities.
\end{abstract}

Key words: School Development Associations, Challenges, Secondary Schools, High Density.

\section{Introduction}

The attainment of independence in Zimbabwe in 1980 led to many reforms in the socio-economic political and education spheres (Zvobgo, 1994). In education, the government wanted to redress the injustices of the colonial past where whites had a policy of separate racial development which favoured them. Education was declared a basic right. According to the Education Act of 1987, the provisions included compulsory and free education. For this reason, the government over committed itself financially because of pressure for more education facilities in terms of classrooms, furniture and books.

Mumbengegwi (1995) states that the number of government secondary schools increased from 70 in 1979 to 192 in 1990. This meant an increase of $122(174 \%)$. The pressure on the government to redress the previous imbalances meant rapid growth, reconstruction and construction of primary and secondary schools. This also meant an increase in the provision and maintenance of services. By the late 1980s, the government's financial resources had been stretched to the limit. The situation was exacerbated by Brenton Wood's recommended austerity measures such as Structural Adjustment Programme (ESAP). As noted by Kanyongo (2005:71): 'The introduction of the program required the government to cut expenditure in social services sectors including education... The government scrapped a lot of subsidies. ... The cumulative effects of these measures ... have been devastating particularly concerning education of children....'

In our view, the government's challenges in funding the education sector adequately gave rise to the 1991 Education Act which led to the formation of School Development Committees (SDCs) in nongovernmental schools. SDCs paved way for the involvement of parents in the financial matters of schools. Statutory Instrument 70 of 1993 provided for the establishment of SDAs in government schools. Like SDCs, SDAs were meant to augment government efforts in developing schools. The government introduced SDAs as a cost sharing measure.

There was nothing untoward regarding the involvement of parents in school development, as argued by Hill (2009), effective schools involve parents as partners in the education process. Similarly, Ngidi (2004) in Mestry and Grobler (2007:176) opines that: '. . . many governments in both the developed and developing worlds are supporting a greater decentralization of school governance and empowerment of interest groups for a variety of perceived political, economical and educational benefits.'

This study sought to interrogate the experiences of SDAs in their quest to be actively involved in the development of schools. It was guided by the following questions: (a) How do SDAs raise finance for school development? (b) What challenges do SDAs experience in raising and managing finances? (c) What strategies can be put in place to enhance the effective operation of SDAs? 


\section{Review of related literature}

In Zimbabwe, SDAs came into existence mainly as a cost sharing strategy (Secretary's Circular, Minute No. 3 of 1991). According to the circular, the SDA should have a minimum of seven and a maximum of eleven members. The members include parents and or guardians of children at the school, the school head and the deputy head. The members of the executive committee elect amongst themselves a chairperson, vice chairperson, secretary and treasurer. Some of the roles of the SDAs include:

- Assist as far as possible in the operation, extension and development of the schools;

- Assist in the preservation and maintenance of the property and facilities of the school;

- Subject to prior consultation with the school head and the approval of the Permanent Secretary of Education, Sports and Culture undertake the construction and installation of new buildings and facilities and carry out alterations, additions, improvements or repairs to existing buildings;

- With the approval of the Permanent Secretary of Education, Sports and Culture, change or impose a levy payable in respect of each child enrolled at the school;

- Submit to the Permanent Secretary of Education, Sports and Culture, on request annual audited accounts of the association; and

- To invest any of the funds of the SDA in such a manner as it considers advisable.

\section{SDAs Meetings and their Frequency}

The Statutory Instrument 70 of 1993 states that the executive committee of the SDA should meet twice in each school term. These meetings enable the committee to carry out its functions which include planning, budgeting reviews and evaluations of their programmes and activities. Once a year, the SDA executive committee should hold an Annual Generating Meeting where all parents and guardians of children enrolled in the school should attend. It is during such meetings that successes and failures of the SDA are revealed to the whole parent/guardian body. The meeting provides an opportunity for parents and guardians to receive an audited financial report for the previous financial year. Plans for the year ahead are also discussed at such a meeting.

In our view, holding meetings with parents and guardians of children once a year may be problematic in that underperforming SDAs may stall the developments of schools for long before corrective measures are taken. We are of the view that the schools' responsible authorities (government and district councils) should pull a leaf out of the Chicago experience regarding the supervision of SDAs. According to Hess (1999), in Chicago, Local School Councils (LSCs) or Parents - Teachers' Associations are supervised by District Councils. In this way, the effectiveness of LSC is closely monitored and if necessary poor performing LCSs are removed from office.

\section{Payment of Levies and Administration of School Funds}

SDAs have their main source of funding as levies collected in respect of each pupil in the school. However, non-payment of levy does not result in the exclusion of pupils from school as directed by the Statutory Instrument 70 of 1993. Needless to say this may impact on the SDAs ability to raise funds, while allowing defaulting pupils to attend school. SDAs end up engaging debt collectors to collect money from such children's parents (B-Metro, $8^{\text {th }}$ March, 2011).

Administration of school funds deals with managing the flow of funds in and out of school. This calls for sound financial management skills, which entail the ability to produce income and expenditure budgets to meet operational plans and overall school objectives, skills to formulate procedure and controls in authorizing and processing expenditure as well as maintaining accurate and complete accounting records (Coombs and Hallak, 1987). In Zimbabwe, courts have handled a number of cases where people entrusted with administering public funds convert the funds to their own use. A case in point appeared in the Sunday News of $12^{\text {th }}$ September 2012, where a bursar (school accountant) embezzled funds raised from levies that were paid by parents. The Nziramasanga Commission (1999) also noted that parents' major concern was the calibre of SDA members and their trustworthiness in the proper administration of funds.

From the parents' submissions to the Nziramasanga Commission, it would appear that in some cases, some members of the SDA executives may not have the academic and professional qualifications to competently discharge SDA duties. We are of the view that, SDAs should look beyond the executive members in cases where the capacity of the executive members in handling funds is limited. For example, some of the parents and guardians may already be working in the financial sector as accountants or auditors, progressive SDAs should take advantage of such individuals. As succinctly argued by Liebenberg (2003) in Grobler and Mestry (2007:178): ‘ . . parents have equal strengths and expertise when compared to teachers and they can contribute and receive services on an equal footing and can even share responsibilities and accountability with professional staff in schools.' Grobler and Mestry (2007) further point out that collaboration and communication have been identified as effective strategies for active parent involvement in schools. Collaboration is a process 
in which people (parents and the school personnel) with diverse expertise and experience work together to generate new solutions to mutually defined problems.

\section{Research Methodology}

Qualitative methodology was chosen for this study as the overall purpose of such methodology is to have a better understanding of the phenomenon under investigation (in this case the experiences of SDAs in their quest to develop schools). This methodology also enabled the researchers to interact with participants, conduct interviews, view and understand the phenomenon under investigation from the view of the participants (emic perspective). The study followed a case study design where ten school heads were purposively sampled. The SDA chairpersons of the schools where school heads were sampled automatically became part of the study. Data were generated through face-to-face interviews with the participants, with the two researchers being the main research instruments, since they conducted the interviews, recorded the interview outcomes, made observations, transcribed, segmented and coded the data. Interview proceedings were recorded verbatim with the use of a recording device. Data generation and analysis were cyclical in that partial analysis was done after each interview. This approach ensured that issues emerging from a preceding interview were factored in the succeeding interview. Prior to the major data analysis, interview transcripts were taken back to the study sample for verification.

\section{Data Analysis}

Data were analysed through thematic content analysis. Analysis was preceded by segmenting, coding, code enumeration and categorisation of data into themes and subthemes.

\section{Measures to ensure Trustworthiness}

Whereas the verifiability of quantitative research is assessed in terms of its reliability and validity, qualitative research is perhaps more accurately assessed according to its trustworthiness (Poggenpoel, 1998) in Mafa (2003). In this study, researchers made use of Guba's model for ensuring the trustworthiness of qualitative data. This was achieved through: (a) Making careful sampling decisions. (b) Triangulating data sources as data were generated from school heads as well as chairpersons of SDAs from schools that were being headed by school heads who were part of the sample. (c) Recording interview proceedings verbatim. (d) Verification of transcribed interview outcomes through member checking before the major data analysis. (e) Ensuring intercoder as well as intracoder reliability.

\section{How SDAs raise finance for school development}

\section{Findings and Discussion}

\section{Payment of levies}

Most of the SDA funds were raised from levies. However, there were large discrepancies in terms of levies charged per term, from one school to another. Four of the schools charged $\$ 9$, while four others charged $\$ 28$ per term. The remaining two schools levied parents $\$ 40$ per term. In some schools, development levy was separate from staff incentives, whereas in others, it was just lumped together with development levy. During interviews, participants explained that the amount of money to be paid as levy by parents and guardians is usually agreed on during an Annual General Meeting. Usually, the SDA executive tables a budget - levy to be paid will be based on the budget. At times, parents and guardians may decide on the amount to be paid through a voting system. However, it was noted that in most cases very few parents and guardians attend such meetings. This has led to SDAs to come up with strategies where they send circulars to parents and guardians having a maximum of three suggested figures (amounts) for them to select the figure (amount) they want to adopt as levy.

\section{Civvies Days}

The second source of funds mentioned by both school heads and SDA chairpersons was Civvies' Days. These are days when pupils are allowed to come to school in their civilian clothes, and requested to pay one dollar each. Civvies' Days were part of the school calendars. In all the ten schools, the frequency of these days was the same - once a month, usually on Friday coinciding with pay days of most parents and guardians. School heads reiterated that the success of Civvies' Days depended to a greater extent on the cooperation of class teachers who were tasked with reminding pupils of the days when they should come in civvies. Class teachers were also actively involved in the collection of Civvies' Day money from pupils who were members of their classes. While Civvies Days have become like a ritual in most schools, SDA chairpersons pointed out that most parents and guardians were against this source of funding. 


\section{Renting out school halls, classrooms and grounds}

SDAs also raised funds from renting out school halls, grounds and classrooms to community members. Such members could be church groups or individual members who could be having functions such as weddings and other social gatherings. Seven schools reported meaningful gains from renting out school facilities, despite the risk associated with property deterioration and damage. To mitigate against wanton destruction of school property, school heads and SDA chairpersons reiterated that they hiked their hiring fees to ensure that only those people genuinely looking for facilities will use them. In case of damage to school property, the extra cash raised from the hiked charges could be used for repairs.

\section{Challenges experienced by SDAs in developing schools}

\section{Political interference and economic status of parents and guardians}

SDA chairpersons and school heads bemoaned political interference in the collection of levies. The born of contention being that some aspiring holders of political and civic offices such councillorship, discourage parents from paying levies when campaigning so as to be voted into office, promising parents and guardians that if elected, they will provide free education services. SDA chairpersons pointed out that even without political interference, most parents and guardians found it difficult to raise money to pay levy. In some instances, while not the best option, SDAs end up engaging debt collectors to assist in the collection of money from defaulting parents. Unfortunately, such a move normally ends up straining relationships between parents and SDAs, who should actually be representatives of parents.

\section{Vulnerable children}

School heads acknowledged the presence of vulnerable children in their schools. These could be orphaned children due to other causes as well as HIV/AIDS, children whose parents could be bed-ridden due to terminal illnesses, children from child-headed families and children whose parents could not raise school fees and levies because of unemployment. In order to cater for these children, the Government of Zimbabwe introduced an intervention strategy the Basic Education Assistance Module (BEAM). School heads and chairpersons of SDAs concurred that where pupils' fees were catered for by BEAM, payments were always made late. The other issue was that beneficiaries of BEAM in a particular term were not automatically qualified to benefit in the subsequent semesters. Training and Research Support Centre and Zimbabwe Teachers Association (2012) note that:

The Beam programme has generally been under funded from the treasury since its inception as a result of the country's constrained fiscal space, creating a number of challenges especially for schools that have a larger share of beneficiaries that solely rely on these funds. Of the estimated 3.6 million children of school going age (primary and secondary), approximately 1 million of them are in need of the assistance according to 2011 BEAM evaluation report, with the Zimbabwe Learning Assessment (ZELA) estimating that about $25 \%$ of the registered children in school are Orphans and Vulnerable Children (OVCs).

\section{Attitudes of parents towards SDA activities}

Interviews revealed that there was apathy amongst most parents and guardians towards fund-raising activities organised by SDAs. Most interviewed school heads and SDA chairpersons, narrated this apathy had narrowed options for raising funds. One school head remarked: If they cannot attend crucial meetings, you think they can attend fundraising activities where they have to pay.

\section{Limited financial knowledge of some of the SDA executive members}

Most school heads raised the concern that some of the parents holding posts that deal with finance may not have the requisite knowledge and skills to competently discharge their duties. They display limitation in budgeting and maintaining financial books among others. At times they fail to account for the funds that will have been used. Some of the SDA chairpersons concurred with the school heads. The cumulative impact of such shortcomings is that, parents - the ones who pay the levy may end up raising eyebrows, thinking that their money meant for the development of the schools is being misused. As a result, SDAs end up encountering challenges when trying to convince parents and/or guardians to pay levy.

We (the researchers) observed a positive relationship between the SDA's leadership and financial management skills and the level of development in the schools. Observations in this area corroborated Grobler and Mestry's (2007) argument that where the SDA leadership is informed, the level of school development is high. This will be evidenced by the quality of infrastructure, level of staff morale, rate of staff turnover, and the schools' pass rates in school leaving examinations, among others. 


\section{Friction between School Heads and SDAs}

Most participants were of the view that development in schools may be derailed by friction between school heads and SDAs. Frequently cited causes of friction by most school heads and SDA chairpersons were: mistrust between the two parties; school heads looking down upon SDAs; both parties not sharing the same vision; either party dictating to the other the course which development should take in the school; lack of transparency; among others. These findings are corroborated by Mupindu (2012: online) who found out that most barriers faced by SDAs include:

. . . lack of parental involvement in school matters, lack of capacity on the part of School Development Committees/Association members ... . lack of good financial management skills by the School Development Committees/Association members, absence of functional finance committees, poor management by school management teams, and poor record keeping by school governors.

\section{Strategies that can be put in place to enhance the effective operation of SDAs}

\section{Payment plan}

The suggestion that schools should come up with a payment plan was raised by an appreciable number of participants. The idea was that SDAs should enter into some binding agreements with parents, detailing how parents and guardians will pay the levy - if they will not be able to pay the total sum at once. The reasoning behind this was that, if spread over a couple of months, even those parents and guardians in the low income bracket could afford to pay. The only concern raised against this approach was that, if more than three quarters of parents and guardians having children in a particular school adopted this approach, the school will take long to accumulate appreciable amounts of money, impacting negatively on school projects where money will be needed immediately.

\section{Visits to school and to other well developed schools}

SDAs and school heads were encouraged to have an open door policy where parents and guardians could come into the schools and taken around, being shown areas needing attention, as well as completed projects. After observing the school's needs, parents and guardians may appreciate, understand and cooperate when money matters are being discussed. Related to this strategy, it was also suggested that school heads and SDAs of underdeveloped schools, should organise visits with groups of parents and guardians representatives to successful and developed schools in the locality. Meetings can be arranged with school heads and SDAs of such schools so that they can share experiences and exchange notes. Such visits may encourage SDAs of struggling schools to emulate and borrow strategies from the developing schools.

\section{Transparency}

Participants suggested that if SDAs were to gain respect and trust from parents and guardians, transparency was very vital. The general feeling was that transparency should be the hallmark of all the activities of the SDAs - voting of office bearers; decisions on how to use SDA funds; amounts of funds collected; availing audited financial statements to parents and guardians; periodic consultation with parents and guardians on financial matters, among others. School heads and SDA chairpersons agreed that if parents and guardians are made aware and are involved in these financial matters, they are bound to cooperate when it comes to payment of levy and other fund-raising activities.

\section{Communication}

Communication was also identified as being at the heart of most successes and failures of SDAs development initiatives. Grobler and Mestry (2007), state that if the schools do not communicate with parents and guardians, they should not blame parents and guardians for their non-involvement. In this age of ICT, suggestions were that SDAs could use strategies such as - cell phones, emails, newsletters and schools' websites. SDAs should create and share visions with parents and guardians of children. They should plan together. Such an approach will ensure that parents and guardians feel that they are part of the development in the schools.

In our view, most challenges experienced by SDAs hinge on the SDAs lack of capacity to initiate and manage development in schools. Therefore, any intervention strategy that overlooks capacity building of SDAs will be synonymous to focussing on symptoms instead of directing efforts on the root cause. As argued by Boostopped and Chikohomero (2011), capacity building may help SDAs: (a) understand and interpret correctly Statutory Instrument 87 of 1992 which gives legal force to the establishment of SDAs; (b) understand and apply 
appropriate financial management of schools; (c) contribute to quality and access of education; and (d) maintain good relations between the school, SDAs and parents.

\section{Conclusions and Recommendations}

Basing on the findings from this study, our conclusions were that:

- Most SDAs had inadequate funds to initiate meaningful developments in the schools;

- The Government Statutory Instrument 70 of 1993 which allows those children who will not have paid their levies to attend school make it difficult for the SDAs to collect money needed for school development;

- Most SDA executive members lacked the essential academic and professional qualifications to enhance their functioning in SDAs, thereby limiting the extent of development in the schools; and

- The delays associated with the disbursement of BEAM funds to schools negatively affect the SDAs cashflows.

Therefore, it was recommended that:

- To address the issue of adequate funds, (a) Determination of levies should be left to SDAs, instead of applying to the Permanent Secretary of Education, Sports and Culture to be given permission to increase the levy and (b) The policy of allowing children who will not have paid levies to remain in schools should be revisited. SDAs should be given the mandate to deal with parents who default on payment of levy.

- Statutory Instrument 70 of 1993 which gave birth to the establishment of SDAs should be amended to include the minimum qualifications required for a parent or guardian to serve in the SDA executive committee.

- Since it is in the interest of The Ministry of Education, Sports and Culture to see schools developing, this parent Ministry should initiate workshops to induct and develop SDA executive members.

- SDAs should be transparent in their operations. They should have their financial books audited by the Ministry of Education, Sports and Culture auditors.

- The Finance Ministry needs to increase the BEAM budget and also disburse the funds to schools on time.

\section{References}

[1]. Boostopped, E. and Chikohomero, R. (2011). School Development Committee Capacity Reinforcement Project in Zimbabwe. SNV Netherlands Development Organisation, Zimbabwe: Harare.

[2]. Coombs, P. H. and Hallak, J. (1987). Cost Analysis in Education: A Tool for Policy Planning and Development. Harare: University of Zimbabwe.

[3]. Government of Zimbabwe. (1987). Education Act. Harare: Government Printers.

[4]. Government of Zimbabwe. (1993). Statutory Instrument No. 70 of 1993 - Education School Development Association Regulations.

[5]. Grobler, B. and Mestry, R. (2007). Parental Involvement in Public Schools. Johannesburg: University of Johannesburg.

[6]. Hess, G. A. Jnr. (1999). Chicago Schools - Reform and Responsibility. www.luc.edu/curb/prag/fall99.pdf. Accessed on 13 May, 2013.

[7]. Hill, N. E. (2010). Parental Involvement in Education. www.gse.harvard.edu/faculty_research/profiles.cv/nancy_hill.pdf. Accessed on 13 May, 2013.

[8]. Kanyongo, G. Y. (2005). Zimbabwe's publication education system reforms: Successes and Challenges. International Education Journal, 6(1): 65-74. http://iej.cjb.net. Accessed 15 May, 2013.

[9]. Mafa, O. (2003). Optimising Mixed-Ability Grouping for Effective Instruction at the Junior Secondary School Level in Botswana. Unpublished Thesis. Pretoria: University of South Africa.

[10]. Ministry of Education, Sports and Culture. (1991). Secretary's Circular, Minute No. 3 of 1991.

[11]. Mumbegegwi, S. C. (1995). Education Planning and Development. Harare: University of Zimbabwe.

[12]. Mupindu, W. (2012). The Capacity of the School Development Committees/Associations towards Providing School Instructional Resources in Zimbabwe. http://www.onlineresearchjournals.org/JSS, 1(7): 200-212. Accessed on 14 ${ }^{\text {th }}$ May, 2013.

[13]. Nziramasanga, T. C. (1999). Report of the Presidential Commission of Enquiry Into Education and Training. Harare: Government Printers.

[14]. The Editor, (2011). B-Metro, $8^{\text {th }}$ March. Bulawayo: Zimpapers.

[15]. The Editor, (2012). The Sunday News. Bulawayo: Zimpapers.

[16]. Training and Research Support Centre (TARSC) and Zimbabwe Teachers Association (ZIMTA). (2012). Tracking the Governance and Accountability of the Basic Education Assistance Module (BEAM) in Ten Districts of Zimbabwe. Harare: TARSC.

[17]. Zvobgo, R. J. (1994). Transforming Education: The Zimbabwe Experience. Harare: College Press. 